\title{
Determination of Cohesive Parameters for Mode II of Epoxy Adhesive
}

Tomáś Kalina

Department of Machine Design, Faculty of Mechanical Engineering, University of West Bohemia, 30614 Pilsen. Czech Republic. E-mail: tkalina@kks.zcu.cz

The paper deals with the determination of cohesive parameters of adhesive Scotch-Weld DP490 3M. Mode II of cohesive damage were examined. Experimental testing was performed on the test specimens to determine the mechanical properties of the adhesive according to ASTM D7905. The results of the experimental testing were compared with the numerical simulation of the same test. The cohesive parameters of the adhesive were obtained from the numerical simulation. Cohesive parameters of adhesive can be used to design real complex adhesive bonded joints. Cohesive models (specifically cohesive contacts or cohesive elements) are one of the most accurate methods of modeling adhesive bonded joints, so this method is mainly used for parts where it is necessary to ensure sufficient strength, such as in automotive, aviation, etc. Based on numerical simulation cohesive parameters of adhesive Scotch-Weld DP490 for mode II were obtained. Critical value of the strain energy release for Mode II conditions $\left(\mathrm{G}_{\text {IIc }}\right)$ was determined to be equal to $2321.3\left[\mathrm{~J} / \mathrm{m}^{\wedge} 2=\mathrm{N} / \mathrm{m}\right]$. Stiffness of the adhesive $\left(k_{I I}\right)$ was determined to be equal to $140[\mathrm{GPa} / \mathrm{m}]$.

Keywords: Cohesion, Strain energy, Scotch-Weld DP490 3M, Mode II, ENF

\section{Introduction}

Composite materials are becoming more and more used materials not only in aerospace and automotive industries but also in other industrial sectors where a high strength and stiffness at low weight is required [1], [2], [3], [4]. In aerospace and automotive industries (for luxury and sports car) the fiber reinforcement composite materials are most frequently used. For joining of those composite materials with metals the adhesive bond is most frequently the best option. The advantages of adhesive bonds are that they have not Heat-affected zone (such as welding [9]) and they do not need to drill holes (stress concentrators).

Within our research we are designing the methodology of predicting the strength of bonded composite material with metals when designing their structure. With the use of experimental testing and numerical simulations. In practice this methodology should be simply applicable to the majority of real components.

The overall quality of the adhesive bond is influenced by many factors. To the most significant ones belong: the material of adhesive components, the surface treatment of adhesive areas [10], the quality of degreasing of adhesive areas (These factors were examined [11]). Another, but no less important, factors are the type of adhesive, the thickness of adhesive layer, the technology of adhesion, etc.

On adhesion properties, specifically on influence material of adhesive components and the surface treatment of adhesive areas were focused the paper [11].
This paper is focused on cohesive properties [16] of adhesive, especially on critical strain energy release rate for mode II ( $\left.\mathrm{G}_{\text {IIc }}\right)$, stiffness of the adhesive $\left(\mathrm{k}_{\mathrm{II}}\right)$ and maximum load force $\left(\mathrm{F}_{\mathrm{C}}\right)$.

Cohesive properties of adhesive are linked with specific type of adhesive. Cohesive properties of adhesive are not dependent on the material of adhesive components, the surface treatment of adhesive areas and the quality of degreasing of adhesive areas. However, high strength adhesives can often cause adhesion failure. Therefore it is very important to design a suitable combination of ,material-adhesive-surface treatment".

The goal of this article is to determine the cohesive properties of epoxy adhesive Scotch-Weld DP490 3M. In this case it is the determination of cohesive parameters for mode II specifically.

\section{Cohesive properties}

There are three independent fracture modes. The crack opening mode (Mode I) is described in detail in [8]. The in-plane shear mode (Mode II) and out-plane shear mode (Mode III) always possess very similar values of fracture toughness and stiffness. That is the reason why only parameters for mode II are often determined and mode III is considered the same. There is also a combination of these modes called 'Mixedmode'. The individual modes of crack opening are shown in Figure 1. [6] Particular cohesive models are given in [5], [6], [13], [14]. Complex methodology of adhesive bonded joints design is described in [7]. 

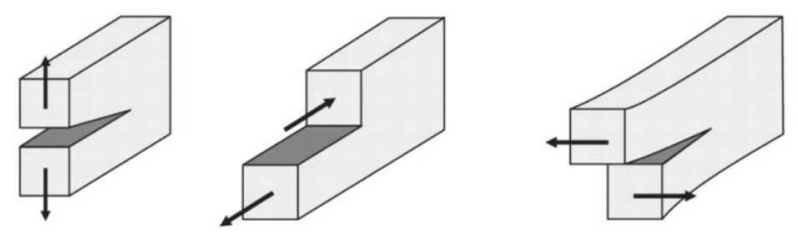

Fig. 1 The crack opening modes (a) Mode I; (b) Mode II; (c) Mode III

\section{Specimens}

The dimensions of the specimens were defined by standard ASTM D7905 [15] for ENF test - mode II. ENF stands for End Notched Flexure. This standard does not define the exact dimensions of the specimen, but ranges of each parameters (Table 1). The shape of the specimens is shown in Figure 2.

Tab. 1 Dimensions of specimen according to ASTM D7905

\begin{tabular}{|c|c|c|c|}
\hline $\begin{array}{c}\text { Para- } \\
\text { meter }\end{array}$ & Name & $\begin{array}{c}\text { Norm } \\
\text { dimensi- } \\
\text { ons [mm] }\end{array}$ & $\begin{array}{c}\text { Selected } \\
\text { dimen- } \\
\text { sions } \\
\text { [mm] }\end{array}$ \\
\hline $\mathrm{L}$ & $\begin{array}{c}\text { specimen } \\
\text { half-span }\end{array}$ & 50 & 50 \\
\hline $\mathrm{L}_{\mathrm{c}}$ & $\begin{array}{c}\text { Overhang closer } \\
\text { to } \mathrm{a}_{0}\end{array}$ & $\geq 15$ & 25 \\
\hline $\mathrm{L}_{\mathrm{u}}$ & $\begin{array}{c}\text { Overhang further } \\
\text { from a }\end{array}$ & $\geq 15$ & 55 \\
\hline $\mathrm{a}_{0}$ & $\begin{array}{c}\text { initial } \\
\text { delamination length }\end{array}$ & 30 & 30 \\
\hline $\mathrm{a}_{\mathrm{i}}$ & $\begin{array}{c}\text { insert length in the } \\
\text { trimmed specimen }\end{array}$ & $\geq 45$ & 75 \\
\hline $\mathrm{R}_{1}$ & $\begin{array}{c}\text { radius of the } \\
\text { loading roller }\end{array}$ & $4.7 \div 9.6$ & 5 \\
\hline $\mathrm{R}_{2}$ & $\begin{array}{c}\text { radius of the support } \\
\text { rollers }\end{array}$ & $3.0 \div 6.0$ & 5 \\
\hline $\mathrm{B}$ & specimen width & $19 \div 26$ & 20 \\
\hline $\mathrm{T}$ & specimen thickness & $3.4 \div 4.7$ & 3.5 \\
\hline
\end{tabular}
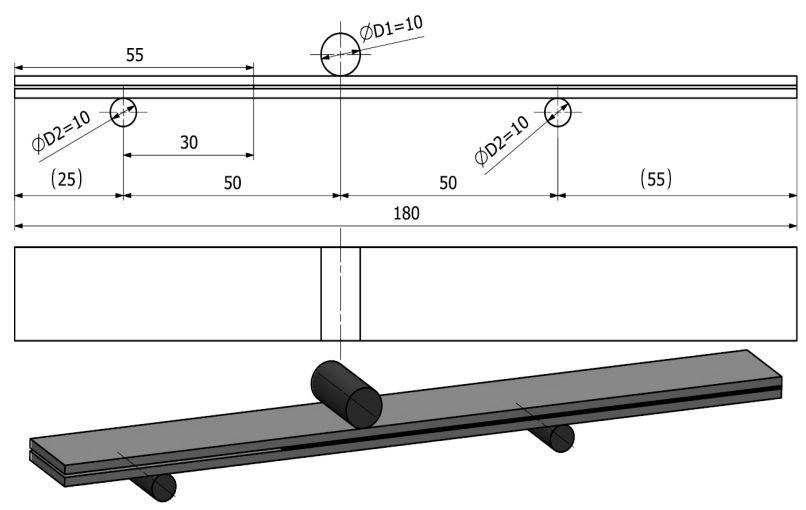

Fig. 2 Dimensions of specimens ENF test

The specimens were made using a water jet cutting machine. The advantage of using water jet cutting is that it achieves very good sample size accuracy. However, it is necessary to use the appropriate machine settings. In general, low pressure with gradually increased water pressure and early abrasive flow is optimal for composite laminate machining [12]. The individual parameters of the material are given in Table 2.

Tab. 2Material properties of the samples

\begin{tabular}{|c|c|c|}
\hline Shortcut & Name & Value \\
\hline $\mathrm{E}_{11}$ & $\begin{array}{c}\text { Young's Modulus } \\
\text { axial direction }\end{array}$ & $31[\mathrm{GPa}]$ \\
\hline $\mathrm{E}_{22}$ & $\begin{array}{c}\text { Young's Modulus } \\
\text { transverse direction }\end{array}$ & $29[\mathrm{GPa}]$ \\
\hline $\mathrm{E}_{33}$ & $\begin{array}{c}\text { Young's Modulus } \\
\text { normal (out-of-plane) direction }\end{array}$ & $15[\mathrm{GPa}]$ \\
\hline $\mathrm{G}_{12}$ & $\begin{array}{c}\text { Shear Modulus } \\
\text { axial direction }\end{array}$ & $4.4[\mathrm{GPa}]$ \\
\hline $\mathrm{G}_{13}$ & $\begin{array}{c}\text { Shear Modulus } \\
\text { transverse direction }\end{array}$ & $4.4[\mathrm{GPa}]$ \\
\hline $\mathrm{G}_{23}$ & $\begin{array}{c}\text { Shear Modulus } \\
\text { normal (out-of-plane) dir. }\end{array}$ & $3.9[\mathrm{GPa}]$ \\
\hline$\nu$ & $\begin{array}{c}\text { Poisson's Ratio } \\
\text { in plane }\end{array}$ & $0.13[-]$ \\
\hline
\end{tabular}

\section{Experimental testing}

Experimental testing of samples was performed on the Zwick/Roell Z050 machine. It is a static material testing machine with a maximum force of $50 \mathrm{kN}$, equipped with extensometers and several types of jaws.

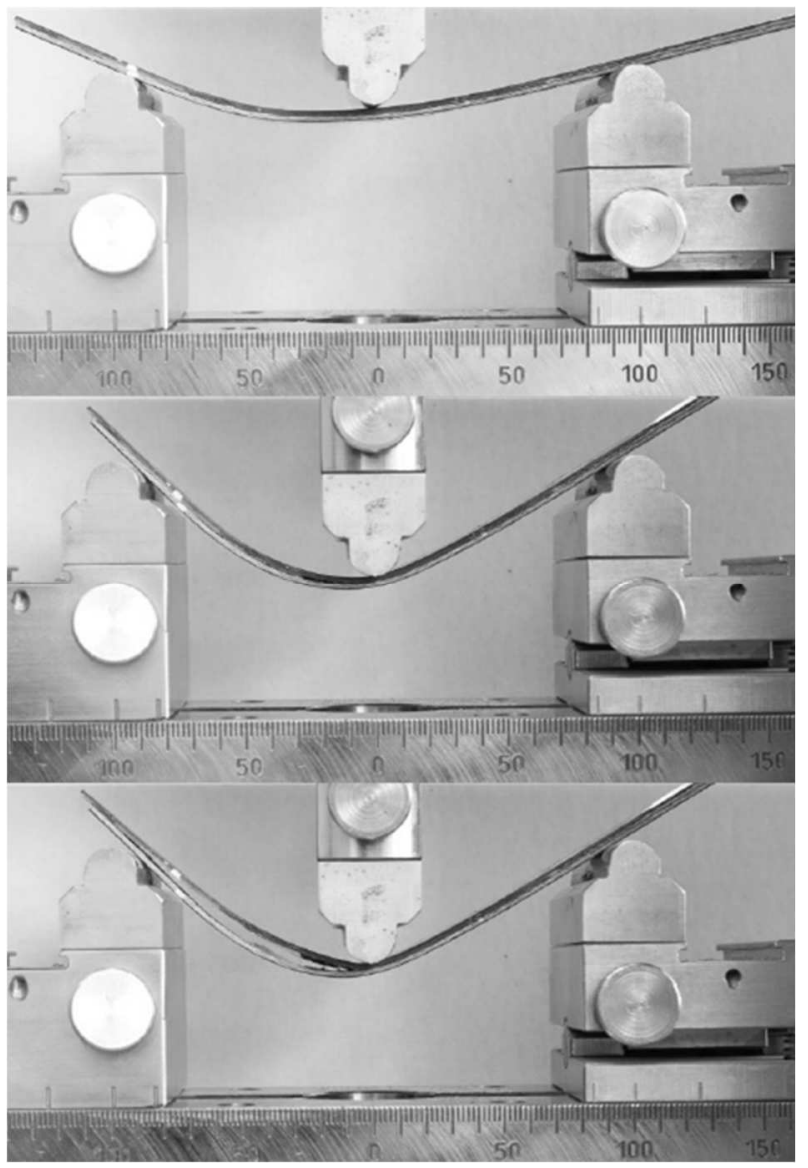

Fig. 3 Progress of the ENF test in several selected phases 
The samples are placed on two support rollers and by means of a load roller, the sample is pressed in the center. The testing happened quasi-statically. The speed of jaws's shift was set to $1.5 \mathrm{~mm} / \mathrm{min}$ according to ASTM D7905 [15]. In this measurement, the loading force $[\mathrm{N}]$ and the displacement $[\mathrm{mm}]$ of the samples were subtracted using extensometers. The figure 3 shows the progress of the ENF test in several selected phases.

\section{Numerical simulation}

Cohesive model is created in software Abaqus 6.14. This is a nonlinear solution. Laminate beams are made of 3D elements (type BRICK). Dimensions and material properties are the same as for real test specimens (Figure. 2, Table 2). A cohesive contact is set between two beams. The specimen is placed on two support rollers (with contact) and on set points is aplied forced displacement. Lower surface of support rollers is fixed.

Computational model of ENF test is given in Figure 4. Examples of results of numerical simulation of ENF test are shown in Figure 5 and 6. Results of numerical simulation and experimental testing ENF tests are given in Figure 7.

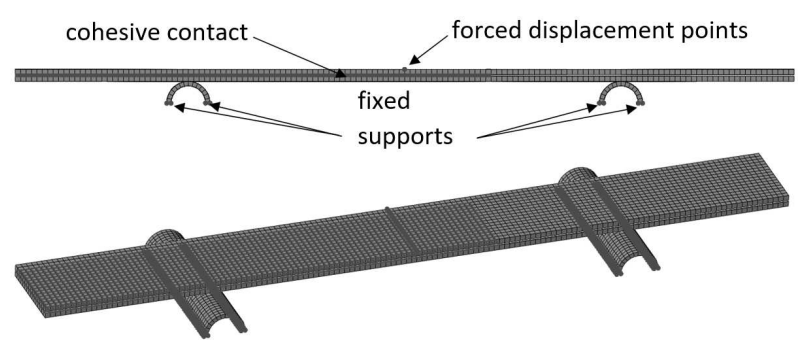

Fig. 4 Numerical model

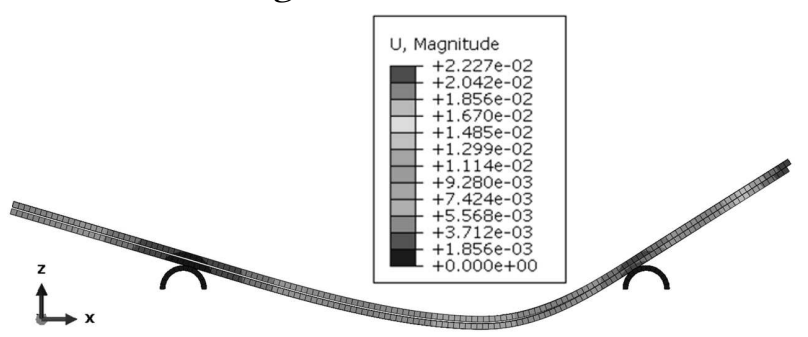

Fig. 5 Example of results of numerical simulation ENF test - results of displacement (m)

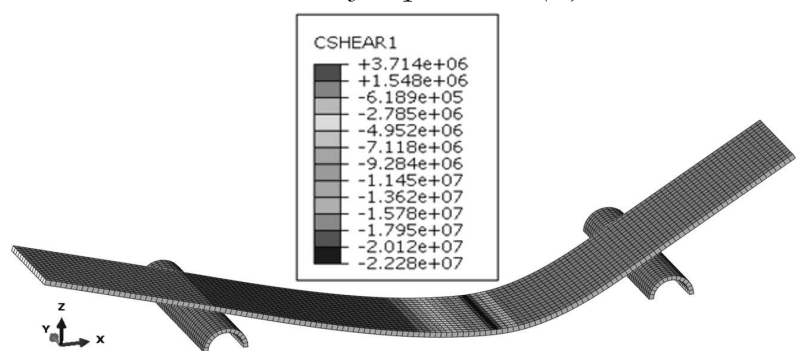

Fig. 6 Example of results of numerical simulation ENF test - results of shear stress $(\mathrm{Pa})$

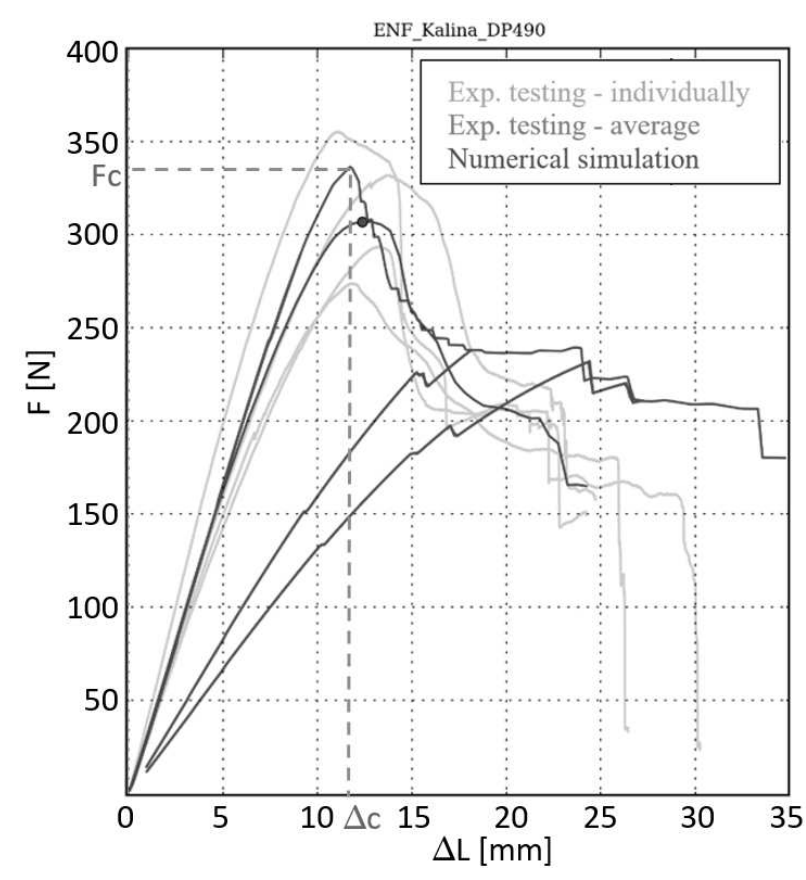

Fig. 7. Results of numerical simulation and experimental testing ENF tests

\section{Summaries of the obtained parameters}

We are interested in stiffness of the adhesive $\left(\mathrm{k}_{\mathrm{II}}\right)$, maximum load force $\left(\mathrm{F}_{\mathrm{C}}\right)$ and critical value of the strain energy release for Mode II conditions $\left(G_{\text {III }}\right)$ for design and simulation of the adhesive bonded joints.

Using experimental testing and numerical simulations, we obtained the necessary parameters:

$$
\begin{gathered}
\mathrm{k}_{\mathrm{II}}=140[\mathrm{GPa} / \mathrm{m}] \\
\mathrm{Fc}_{\mathrm{CI}}=335 \mathrm{~N} \\
\Delta \mathrm{c}_{\mathrm{II}}=11.7 \mathrm{~mm} \\
\mathrm{G}_{\text {IIc }}=2321.3 \mathrm{~J} / \mathrm{m}^{\wedge} 2
\end{gathered}
$$

Where: $\Delta \mathrm{c}_{\text {II }}$ is value of displacement appropriate to Fc.

We already know cohesive parameters for mode I for cohesive parameters of adhesive Scotch-Weld DP490 3M from [8].

$$
\begin{gathered}
\mathrm{k}_{\mathrm{I}}=200[\mathrm{GPa} / \mathrm{m}] \\
\mathrm{Fc}_{\mathrm{I}}=26.66 \mathrm{~N} \\
\Delta \mathrm{c}_{\mathrm{I}}=21.393 \mathrm{~mm} \\
\mathrm{G}_{\mathrm{Ic}}=905.5 \mathrm{~J} / \mathrm{m}^{\wedge} 2
\end{gathered}
$$

Usually we require that the adhesive bonded joint is operated before the first failure. The first part (from 0 to $\Delta \mathrm{c}$ ) of the chart (Fig.7) describes the stiffness of the adhesive (to the first failure). The second part (after $\Delta \mathrm{c}$ ) of the chart describes the damage progress. Therefore, the accuracy in the first part of the chart is more important to us. However, it may sometimes be useful to model the progress of material failure. We 
can simulate progress of material failure using cohesive parameters.

Because we already know cohesive parametres for mode I and mode II and parametrs for mode III can be considered identical to the parametrs of mode II, we have everything you need for modeling complex adhesive bonded joints in numerical simulations. Comprehensive design methodology of adhesive bonded joint is described in detail in [7].

\section{Conclusion}

The goal of this article was to determine the cohesive properties of mode II of epoxy adhesive ScotchWeld DP490 3M. Experimental testing of samples was performed and compared with numerical simulation of ENF tests.

Based on numerical simulation cohesive parameters of adhesive Scotch-Weld DP490 for mode II were obtained. Critical value of the strain energy release for Mode II conditions ( $\mathrm{G}_{\text {IIC }}$ ) is equal to 2321.3 $\left[\mathrm{J} / \mathrm{m}^{\wedge} 2=\mathrm{N} / \mathrm{m}\right]$. Stiffness of the adhesive $\left(\mathrm{k}_{\mathrm{II}}\right)$ is equal to $140[\mathrm{GPa} / \mathrm{m}]$. Critical force $\left(\mathrm{Fc}_{\mathrm{II}}\right)$ is equal to $335 \mathrm{~N}$ and displacement appropriate to critical force $\left(\Delta \mathrm{c}_{\mathrm{II}}\right)$ is equal to $11.7 \mathrm{~mm}$. Obtained cohesive parameters of adhesive can be used to design real, shape complicated adhesive bond. We have everything you need for modeling complex adhesive bonded joints in numerical simulations.

\section{Acknowledgments}

This paper is based on work sponsored by project SGS2019-001 (The complex support of designing of technical equipment IV).

\section{References}

[1] GAY, D., HOA, S. V., TSAI, S. W. (2003). Composite materials - design and applications, Boca Raton, London, New York, Washingtom, D.C.: CRC Press LLC.

[2] DANIEL, I. M., ISHAI, O. (1994) Engineering Mechanics of Composite Materials. Oxford: Oxford University Press. 384 pp. ISBN 0-19507506-4

[3] CHUNG, DEBORAH, D. L. (2003) Composite materials: functional materials for modern technologies. London: Springer. 289 pp. ISBN $185233665 \mathrm{x}$

[4] KLEISNER, V., ZEMČÍK, R., KROUPA, (2011). Identification and verification of the composite material parameters for the ladevèze damage model. Materiali in Tehnologije, vol. 45, no. 6 , pp. $567-570$

[5] BERNARDIN, P., SEDLACEK, F., KROUPA, T., LASOVA, V.; HANZLÍK, P.
(2016). Identification of the cohesive parameters for modeling of adhesively bonded joints between flat epoxy composite adherends. Materiali in tehnologije 2016.

[6] SKOVAJSA, M., SEDLACEK, F. (2017) Numerical simulation of delamination in laminated composite plates using cohesive elements, 27TH DAAAM International symposium on intelligent manufacturing and automation, DOI:10.2507.

[7] KALINA, T., SEDLACEK, F. (2019). Design and Determination of Strength of Adhesive Bonded Joints. In: Manufacturing Technology, pp.409-413, Vol.19, No.3. UJEP, 2019, ISSN: 1213-2489, DOI: 10.21062/ujep/305.2019/a/1213 $2489 / \mathrm{mt} / 19 / 3 / 409$

[8] KALINA, T., SEDLACEK, F., KROUPA T. (2018). Determination of cohesive parameters for mode I of epoxy adhesive. Proceedings of the 29th DAAAM International Symposium, pp.07460751, B. Katalinic (Ed.), Published by DAAAM International, ISBN 978-3-902734-20-4, ISSN 1726-9679, Vienna, Austria

[9] KALINA, T., HELLER, P., CHVAL, Z., SEDLACEK, F., KRIZEK, M., BARTON, L. (2018) Numerical Simulation and Experimental Testing of Two-axle Chassis of Low-floor Trams, Manufacturing Technology: journal for science, research and production. Vol. 18, No. 2. Ústí nad Labem: Univerzita J.E. Purkyně, 2018. ISSN 1213-2489.

[10] KOLÁŘ, V., MÜLLER, M., TICHÝ, M., RUDAWSKA, A., HROMASOVÁ, M. (2019). Influence of preformed adherent angle and reinforcing glass fibre on tensile strength of hybrid adhesive bond. In: Manufacturing Technology, pp.786-791, Vol.19, No.5. UJEP, 2019, ISSN: 1213-2489, DOI: 10.21062/ujep/372.2019/a/12132489/MT/19/5/786

[11] KALINA, T., SEDLACEK, F., KRYSTEK, J. (2018). Determination of the influence of adherent surface on the adhesive bond strength, The 22nd International Slovak - Polish Conference on $\mathrm{Ma}$ chine modelling and Simulations 2017, Sklené Teplice, Slovakia, MATEC Web of Conferences, volume 157, 14 March 2018, Article number 05012, ISSN: 2261236X

[12] KIM, G., DENOS, B.R., STERKENBURG, R. (2020). Influence of different piercing methods of abrasive waterjet on delamination of fiber reinforced composite laminate. In: COMPOSITE STRUCTURES, Vol.240, 
Art.no.: 112065, ISSN: 0263-8223, DOI: 10.1016/j.compstruct.2020.112065

[13] BERNARDIN, P., VACÍK, J., KROUPA, T., KOTTNER, R. (2013). Determination of the mechanical parameters of a bonded joint between a metal and a composite by comparing experiments with a finite-element model. Materiali in Tebnologije, vol. 47, no. 4, pp. 417-421.

[14] SRBOVÁ, H., KROUPA, T., ZEMČÍK, (2014). Identification of the initial failure and damage of substituents of a unidirectional fiber-reinforced composite using a micromodel. Materiali in Tehnologije, vol. 48, no. 4, pp. 549-553.
[15] Standard Test Method for Determination of the Mode II Interlaminar Fracture Toughness of Unidirectional Fiber-Reinforced Polymer Matrix Composites, Designation: D7905/D7905M

[16] KOTTNER, R., HYNEK, R., KROUPA, T. (2013). Identification of parameters of cohesive elements for modeling of adhesively bonded joints of epoxy composites. In: Applied and Computational Mechanics, Vol. 7, No. 2, pp. 137-144. ISSN: 1802-680X 